\title{
Evaluation of Some Biological Agents and Plant Extracts for Controlling Cucumber White Rot caused by Sclerotinia sclerotiorum (Lib) de Bary
}

\author{
Yasmine M. Elbatawy, Fathy G. Mohamed, Nawal A. Eisa and Mohamed H. El-Habbak \\ Plant Pathology Department, Faculty of Agriculture, Moshtohor, Benha University, Egypt.
}

Corresponding Author: yasmin.elbatawy@fagr.bu.edu.eg

\begin{abstract}
Five Trichoderma isolates, two bacterial bioagents and six different plant extracts compared with five commercial fungicides. All materials were tested individually and in combinations bothin vitro and in vivo against white rot disease of cucumber caused by Sclerotinia sclerotiorum. All tested bio-agents, plant extracts, and fungicides caused significant growth reduction of S. sclerotiorum. Trichoderma hamatum caused the highest reduction followed by T. viride and T. harzianum. Bacillus subtilis was better than Pseudomonas fluorescens in reducing growth of $S$. sclerotiorum, meanwhile, all tested biocides reduced the mycelial growth and sclerotia formation at their highest concentrations. Also, both linear growth and production of sclerotia of S. sclerotiorum were significantly reduced by all tested plant extracts compared to control. Moreover, all fungicides caused complete inhibition of growth and sclerotia formation of S. sclerotiorum. Under greenhouse conditions, T. album and T. harzianum- 2 were the most effective treatments for disease management followed by B. subtilis and $P$. fluorescens. Neem extract was the most effective as it reduced disease incidence and disease severity and increased fresh and dry weight of shoot and root followed by onion and lemongrass extracts. Moreover, the highest reductions of disease incidence and severity were obtained in case of Bellis and Onest 70\% fungicides. However, all tested commercial biocides significantly reduced white rot disease incidence and severity, as well as increased the fresh and dry weight of shoot and root. Applying the different combinations of the previous tested management methods with varietal resistance as integrated management approaches resulted in their significance in reduction of white rot disease incidence and disease severity, as well as the improvement of some growth characters.
\end{abstract}

Key words: White rot. Sclerotinia sclerotiorum, cucumber, integrated management.

\section{Introduction}

Cucumber (Cucumis sativus L.) is one of the most important vegetable crops all over the world. Fresh cucumber fruits are important for the human nutrition and health, which contain flavor and essential nutrients such as vitamins and minerals, especially potassium and magnesium. It is also a major source of fiber, complex carbohydrates, antioxidants and anticarcinogenic substances (Arul $\boldsymbol{e t}$ al., 1994).

One of the purposes of growing crops under protected cultivation is to protect the plants from the adverse environmental conditions as well as to avoid many fungal, bacterial, viral and root knot nematode that affect fruit yield. However, the greenhouse conditions are favorable for occurrence of fungal diseases due to the high humidity, especially, root rot and white (Sclerotinia) rot (Abd-El-kareem, 2009). Sclerotinia sclerotiorum (Lib.) de Bary, the causal agent of white rot, is one of the most devastating and cosmopolitan plant pathogens, which can cause numerous diseases of over 400 species of plants worldwide (Bolton et al., 2006). It spreads primarily by spores and sclerotia, which could infect stems, leaves, flowers and siliquesof adjacent plants (Zhou and Boland, 1998). Sclerotia of S. sclerotiorum could reside in the soil for several years and, when appropriate environmental conditions exist, germinate either in a myceliogenic manner, giving rise to infective hyphae, or by carpogenic germination to produce apothecia, which release millions of sexually produced, air-borne ascospores (Bardin and Huang, 2001).

The fungicidal application has been found to be much more effective than cultural practices for the management of fungal diseases, including white rot of cucumber, either in field or in greenhouse, accordingly, it is the most commonly used means up to date (Fravel, 2005). On the other hand, chemical synthetic fungicides are hazardous and toxic to humans, animals, cause environmental pollution, have negative environmental impact and their efficacy probably decrease over time (Wang et al., 2015). Therefore, there is a growing need to develop alternative approaches for controlling plant diseases that are safe for human, animals and environment. The introduction of beneficial microorganisms into soil or the rhizosphere has been proposed for the biological control of soil-borne plant diseases, including white rot (Abd-El-Kader et al., 2013).

This work was designed to isolate and identify the fungi associated with the infected cucumber tissues collected at selected locations in Egypt, and evaluate commercial fungicides, plant extracts and biological control agents (fungal and bacterial) in vitro and in vivo against the pathogen of white rot. 


\section{Materials and methods:}

\section{Collection of infected plant materials:}

Cucumber plants showing identical Sclerotinia rot symptoms on stems and fruits were collected from different field locations in Egypt; i.e. Al-Qalyubia (Moshtohor), Al-Qalyubia (Toukh), El-Behira (Elbostan), Kafr Elsheikh (Kafr Elsheikh) and South Sinai, during winter 2016 growing season.

\section{Isolation and identification of the pathogen:}

Collected samples were subjected to isolation trials. The infected tissues (lesions) were cut into small pieces and were surface sterilized with sodium hypochlorite $(0.5 \%)$ for 3 minutes, then washed several times with sterilized distilled water and dried between sterilized filter papers and transferred directly to the PDA medium in $9 \mathrm{~cm}$-Petri dishes. The plates were incubated for 3 days at $22 \pm 2^{\circ} \mathrm{C}$. Fungi grown from the cultured pieces were transferred to potato dextrose agar (PDA) slants. Fungal isolates were purified by hyphal tip technique (Brown, 1924) and kept on PDA slants at $5^{\circ} \mathrm{C}$. Pure isolates were identified according to the morphological characteristics of mycelium, microconidia and germinating sclerotia with apothecial head as mentioned by Singh, 1982.

\section{Pathogenicity Tests:}

S. sclerotiorum isolates were tested for their pathogenicity on apparently healthy seedlings. The following technique was adopted in pathogenicity study and in all pot experiments except otherwise indicated in a treatment.

\section{Pot preparation:}

Loamy sand soil (3 clay:1 sand w/w) was sterilized by thoroughly mixing with $5 \%$ commercial formalin solution (one liter of $5 \%$ formalin solution $/ 30 \mathrm{~cm}^{3}$ of soil mixture) and covered with polyethylene for 2 weeks. Later, polyethylene cover was removed, and soil was raked for 10 days for ventilation and formalin evaporation. Similarly, plastic pots $(\varnothing 30 \mathrm{~cm})$ were sterilized by dipping in $5 \%$ commercial formalin solution for 15 minutes, left to dry for $24 \mathrm{~h}$ then filled with the previously sterilized soil.

For soil infestation, inocula of the tested isolates were prepared using loamy soil artificially infested individually (at the rate of $3 \% \mathrm{w} / \mathrm{w}$ ) with a primary inoculum of each tested isolate which previously grown on sand barley medium $(1: 1, \mathrm{w} / \mathrm{w}$ and $40 \%$ water) for two weeks (Abdel Kader et al., 2012). Inoculum of each isolate of S. sclerotiorum fungus was added to the potted soil at rate of $3 \% \mathrm{w} / \mathrm{w}$, mixed thoroughly with the soil surface of each pot then watered and left for one week to insure even distribution of the inocula. Then, the pots were placed in a dew chamber with $100 \%$ relative humidity at $22^{\circ} \mathrm{C}$ \pm 3 for $48 \mathrm{~h}$, then moved into the greenhouse. Healthy cucumber transplants of Torpedo hybrid (from
Sersellayyan nurseries, El-menoufeya) were planted immediately at the rate of three seedlings per pot. Three replicates (pots) for each treatment were used. And three replicates were used without inocula as a control.

The number of plants having specific cottony rot (white rot) disease symptoms was counted after 60 days from planting and the percentage of infection was calculated according to Hovius and Goldman 2004 as follows;

$\begin{aligned} & \text { Infection } \\ & \text { percentage }\end{aligned}=\frac{\text { No. of transplants infected with white rot }}{\text { Total No. of planted transplants }} \times 100$

The disease severity of white rot that caused by $S$. sclerotiorum was assessed using disease scale proposed by Grau et al., 1982 consisted of three categories: 0 to 3 , where; $(0=$ no detectable symptoms, $1=$ appearance of a 1-2 cm water-soaked lesion on the crown region of the plant, $2=$ appearance of a $2 \mathrm{~cm}$ water-soaked lesion covering the stem base of the plant, $3=$ plant completely dead). The of disease severity was calculated according to Grau et al., 1982 as follows;

Disease Severity $\%=\Sigma(\mathbf{a} \times \mathbf{b}) / \mathbf{N} \times \mathbf{K} \times 100$

Where: $\quad \mathrm{a}=$ Number of infected plants in each category.

$$
\begin{aligned}
& \mathrm{b}=\text { Numerical value of each category. } \\
& \mathrm{N}=\text { Total number of examined plants. } \\
& \mathrm{K}=\text { The highest degree of infection category }
\end{aligned}
$$

Inocula Preparation:

The pathogen ( $S$. sclerotiorum) was grown on PDA plates for 10 days at $22^{\circ} \mathrm{C}$. Then transferred to sterilized sand barley medium for two weeks (3:1, $\mathrm{w}: \mathrm{w}$ and $40 \%$ water). Inoculum of S. sclerotiorum fungus was added to the potted soil at rate of $3.0 \%$ $\mathrm{w} / \mathrm{w}$, mixed thoroughly with the soil surface e of each pot then watered and left for one week to insure even distribution of the inocula.

The biological agent isolates (Trichoderma harzianum, T. viride, T. hamatum, T. harzianum 2 and T. album) were grown on PDA plates for 10 days at $22^{\circ} \mathrm{C}$. Then transferred to sterilized sand barley medium for two weeks (3:1, w:w and $40 \%$ water) was obtained from Agric. Botany Dept., Fac. Agric. Benha Univ. According to El-Fiki et al., 2001, it was grown on agar Bushnell's medium (Bushnell and Haas, 1941). Plates containing autoclaved Bushnell's agar medium were inoculated, each with a disc 5-mm in diameter of the 7-days old mycelial growth and incubated for 7 days at $28^{\circ} \mathrm{C}$. Then tested isolate which previously had grown for two weeks on sand barley medium (3:1, w:w and $40 \%$ water). Inocula of each isolate of Trichoderma were added to the potted soil at rate of $3.0 \% \mathrm{w} / \mathrm{w}$, mixed thoroughly with the soil surface of each pot $(\$ 30 \mathrm{~cm})$ then watered and left for one week to insure even distribution of the inocula. The biological agents were mixed manually into the soil amended with organic matter (poultry 
fertilizer) at rate $10 \%(\mathrm{w} / \mathrm{w})$ and incubated for 14 days in plastic pots at temperature of $18-20^{\circ} \mathrm{C}$. Seven days before sowing, the potting mixes were inoculated with the pathogen.

\section{Laboratory Experiments:}

Antagonistic activity of biological agents against Sclerotinia sclerotiorum:

In this study, two isolates of Trichoderma ( $T$. harzianum, T. hamatum) were isolated from the rhizosphere of cucumber plants and other three isolates (T. harzianum, $T$. viride, $T$. album) were obtained from Plant Pathology Dept., Fac. of Agric., Benha Univ. Egypt .The tested bacterial bioagents were obtained from Plant Pathology Dept., Fac. of Agric., Ain Shams University. Egypt. using Trichoderma spp. Two discs (Ø 5mm) of 4-days-old plain agar cultures of the antagonistic fungi (Trichoderma harzianum, T. viride, T. hamatum, $T$. album) and S. sclerotiorum isolate No .1 from Toukh of 10 days old were inoculated simultaneously each opposite to the other, $1 \mathrm{~cm}$ apart from the plate edge in individual $9 \mathrm{~cm}$-Petri dishes containing $10 \mathrm{~mL}$ PDA medium. For control, the plates were inoculated with the same isolate of S. sclerotiorum only. Three dishes were used for each particular treatment. All dishes were incubated at $22 \pm 2^{\circ} \mathrm{C}$ for 10 days. Percentage of the fungal growth reduction (X) was calculated by using the following formula suggested by (Abd-ElMoity, 1985).

$$
X=\frac{G_{1}-G_{2}}{G_{1}} \times 100
$$

Where: $\mathrm{X}=$ fungal growth reduction, $\mathrm{G} 1=$ linear growth of the pathogen inoculated alone (control) and G2 =linear growth of the pathogen inoculated against the antagonistic fungus.

For testing the effect of two antagonistic bacteria isolates (Pseudomonas fluorescens and Bacillus subtilis) obtained from Plant Pathology Dept., Fac. of Agric., Ain Shams Univ. Egypt; against S. sclerotiorum isolate No .1 from Toukh; individual dishes $(\varnothing 9 \mathrm{~cm})$ contained PDA medium were streaked at one side $1 \mathrm{~cm}$ apart from the plate edge with a loop full of the antagonistic bacteria (48 hrs- old) grown on nutrient broth medium (NB) and incubated for $24 \mathrm{hrs}$ at $22^{\circ} \mathrm{C}$. Thereafter, the same dish was inoculated at the opposite side, $1 \mathrm{~cm}$ apart of the dish edge with $5 \mathrm{~mm}$ disc of 10 days-old plain agar culture of $\mathrm{S}$. sclerotiorum. All dishes were incubated at $22 \pm 2^{\circ} \mathrm{C}$ for 5 days (Maurhofer et al., 1995).

Evaluation of some commercial biocides on the growth and sclerotia formation of $S$. sclerotiorum:

This experiment was designed to investigate the inhibitory effect of two biocides Plant Guard and Blight Stop (Table 1) from Agriculture research center, on growth of $S$. sclerotiorum in vitro. The biocides used were tested at 3 concentrations; 1,2 and $3 \mathrm{~g} / \mathrm{L}$

Table 1. List of the tested commercial biocides, their active ingredients, manufacturer and rate of use.

\begin{tabular}{llll}
\hline $\begin{array}{l}\text { Commercial } \\
\text { bio-fungicides }\end{array}$ & Active ingredient & Manufacturer & Rate of use \\
\hline Plant Guard & $\begin{array}{l}\text { Trichoderma harzianum } \\
\left(30 \times 10^{6} \text { spore/mL }\right)\end{array}$ & $\begin{array}{l}\text { Bio Tec for fertilizers } \\
\text { and biocides, Egypt }\end{array}$ & $5 \mathrm{~mL} / \mathrm{L}$ \\
\hline Blight Stop (liquid) & Mixture of Trichoderma spp. & $\begin{array}{l}\text { Central lab. of Organic } \\
\text { Agri. (ARC) }\end{array}$ & 1L/100L \\
\hline
\end{tabular}

Effect of different plant extracts on the growth of S. sclerotiorum:

Six different plant extracts (Table 2) that have been found to possess fungicidal properties in vitro were tested for their efficacy in vitro. Each plant leaf and bulbs samples were washed thoroughly in running tap water, air-dried and separately micronized with a hammer mill into a fine powder. Cold water extraction was carried out by adding 5, 10 and $20 \mathrm{~g}$ of the powder of each plant to $100 \mathrm{~mL}$ of distilled water separately in $250 \mathrm{~mL}$ beaker and were left for 24 hours and subsequently filtered through four-fold of sterile cheese cloth. These preparations gave 5, 10 and 20\% crude aqueous extract (Ramesh Singh; 2015).

Table 2. The tested plant extracts, scientific name of the plant, the used part, their concentrations:

\begin{tabular}{llll}
\hline Common name & Scientific name & Extracted part & Concentrations \\
\hline Basil & Ocimum basilicum & Leaves & \\
\hline Garlic & Allium sativum & Bulbs & \multirow{2}{*}{$5 \%, 10 \%, 20 \%$} \\
\hline Lemongrass & Cymbopogon citratus & Leaves & \\
\hline Nerium & Nerium oleander & Leaves & Leaves \\
\hline Neem & Azadirachta indica & Bulbs & \\
\hline Onion & Allium cepa &
\end{tabular}

\section{Effect of the tested fungicides:}

This experiment was designed to investigate the inhibitory effect of five fungicides as in Table 3, on the linear growth of $S$. sclerotiorum in vitro. The fungicides Hesta70\%; Topsin M; Bellis; Onest $70 \%$. used were tested at 3 concentrations. The amount 
required for obtaining a known concentration of any fungicide was calculated and added aseptically to known amount of warm sterilized Czapek's agar medium. The experiment was terminated when mycelial mats covered medium surface and formation the sclerotia in control treatment, all plates were examined, and growth reduction was calculated by using the following formula suggested by (Abd-ElMoity, 1985).

$$
X=\frac{G_{1}-G_{2}}{G_{1}} \times 100
$$

Where: $\mathrm{X}=$ fungal growth reduction, $\mathrm{G} 1=$ linear growth of the pathogen inoculated alone (control) and G2 =linear growth of the pathogen inoculated against the antagonistic fungus.

Table 3: List of the tested fungicides, their active ingredients, chemical formula, manufacture, and rate of use/L.

\begin{tabular}{|c|c|c|c|c|}
\hline Trade name & $\begin{array}{l}\text { Common name \& } \\
\text { Active ingredient }\end{array}$ & Manufacture & Chemical formula & Rate of use/L \\
\hline $\begin{array}{l}\text { Bellis } 38 \% \\
\text { WG }\end{array}$ & $\begin{array}{l}\text { Boscalid } 25.2 \% \text { and } \\
\text { pyraclostrobin } 12.8 \%\end{array}$ & BASF (U.K.) & $\begin{array}{l}\text { Boscalid and pyraclostrobin } \\
\text { (ISO); methyl N-\{2-[1-(4- } \\
\text { chlorophenyl)-1H-pyrazol-3- } \\
\text { yloxymethyl] } \\
\text { phenyl }\}(\mathrm{N}- \\
\text { methoxy)carbamate }\end{array}$ & $\begin{array}{l}0.05 \mathrm{~g} / \mathrm{L} \text { of } \\
\text { water }\end{array}$ \\
\hline Topsin M 70 & $\begin{array}{l}\text { Thiophonate methyl } \\
(70 \%) w p\end{array}$ & $\begin{array}{l}\text { Shoura group for } \\
\text { chemicals, } \\
\text { Egypt }\end{array}$ & $\begin{array}{l}\text { Thiophonate methyl } \\
\text { [dimethyl (1,2- } \\
\text { phenylene)- } \\
\text { bis(iminocarbonothioyl) } \\
\text { bis carbonate } 70 \%\end{array}$ & $\begin{array}{l}0.8 \mathrm{~g} / \mathrm{L} \text { of } \\
\text { water }\end{array}$ \\
\hline Onest $70 \%$ & $\begin{array}{l}\text { Thiophonate methyl } \\
(70 \%) w p\end{array}$ & Maka & $\begin{array}{l}\text { Dimethyle } 4.4(0- \\
\text { phenylene) bis (3- } \\
\text { thiosullophanate) }\end{array}$ & $\begin{array}{l}1 \mathrm{~g} / \mathrm{L} \text { of } \\
\text { water }\end{array}$ \\
\hline Basten $80 \%$ & Carbandazaim $(80 \%)$ wp & $\begin{array}{l}\text { Hepy guanlong } \\
\text { Agrochemicals }\end{array}$ & $\begin{array}{l}\text { Methyl benzimidazole-2- } \\
\text { ylearbamate }\end{array}$ & $\begin{array}{l}0.5 \mathrm{~g} / \mathrm{L} \text { of } \\
\text { water }\end{array}$ \\
\hline Hesta70\% & $\begin{array}{l}\text { Thiophonate methyl } \\
(70 \%) \mathrm{wp}\end{array}$ & Elhelb & $\begin{array}{l}\text { Dimethyle } 4.4(0- \\
\text { phenylene) bis ( } 3- \\
\text { thiosullophanate) }\end{array}$ & $\begin{array}{l}1 \mathrm{~g} / \mathrm{L} \text { of } \\
\text { water }\end{array}$ \\
\hline
\end{tabular}

\section{Greenhouse Experiments:}

Varietal reaction of different commercial cucumber cultivars to white rot pathogen:

This experiment was carried out under greenhouse conditions in January 2017 in the greenhouse of Plant Pathology Department, Faculty of Agriculture, Benha University, Moshtohor, Egypt. The inoculum of $S$. sclerotiorum fungus was prepared as previously mentioned. Seven cucumber hybrids, namely; Hybrid Vector, C.B140, Smile, Matrix, Torpedo, Beta Alpha and Barracuda were transplanted in inoculated plastic pots $(30 \mathrm{~cm}$ in diameter) previously filled with sterilized soil. These seedlings were from Sersellayyan nurseries, El-menoufeya. Three seedlings were transplanted per pot with three replicates for each hybrid. Three seedlings were transplanted per pot with three replicates for each hybrid but without inocula of Sclerotinia as a control.

\section{Application of biological agents for controlling} Sclerotinia rot:

In this experiment, the inoculum of five isolates of Trichoderma spp., i.e (Trichoderma harzianum, $T$. harzianum 2, T. viride, T. hamatum, and T. album) were prepared The biological agent isolates (Trichoderma harzianum, T. viride, T. hamatum, $T$. harzianum 2 and T. album) were grown on PDA plates for 10 days at $22^{\circ} \mathrm{C}+3$. Then transferred to sterilized sand barley medium for two weeks (3:1, w: w and 40\% water)., Inocula of each isolate of Trichoderma were added to the potted soil at rate of $3.0 \% \mathrm{w} / \mathrm{w}$, mixed thoroughly with the soil surface of each pot $(\phi 30 \mathrm{~cm})$ then watered and left for one week to insure even distribution of the inocula. The biological agents were mixed manually into the soil amended with organic matter(poultry fertilizer) at rate $10 \%(w / w)$ and incubated for 14 days in plastic pots at temperature of $18-20^{\circ} \mathrm{C}$. Seven days before sowing, the potting mixes were inoculated with the pathogen.as previously mentioned, and two antagonistic bacteria (Pseudomonas fluorescens and Bacillus subtills) were tested. Bacterial suspensions $\left(1 \times 10^{8} \mathrm{cfu} / \mathrm{mL}\right)$ were prepared by dilution plate assay as described by Callan et al., 1990. Cucumber seedlings were dipped into cell suspension of each of the tested antagonistic bacteria at the rate of $5 \mathrm{~mL} / \mathrm{L}$ for 15 minutes according to Park et al., 1991. Pots were planted with healthy cucumber transplants cv. Torpedo. Three transplants/pot and three replicates for every treatment were used. Transplants were planted in pots amended with mixture of soil with organic matter (poultry fertilizer) or soil without organic matter as well as for the untreated control. Soil infestation was carried out as previously mentioned. The disease severity of 
white rot was assessed using a disease scale mentioned earlier in this section.

Application of two commercial biocides for controlling Sclerotinia rot:

Two commercial biocides i.e. Plant Guard (Table 1) were used as dipping treatment at the rate of $5 \mathrm{~mL} / \mathrm{L}$ and Blight Stop was used as dipping treatment at the rate of $1 \mathrm{~L} \backslash 100 \mathrm{~L}$ as mentioned in biological agents.

Effect of some plant extracts on controlling Sclerotinia rot:

Six different plant extracts, Basil, Garlic, Lemongrass, Nerium, Neem and Onion. At the rate of 5,10 and $20 \%$ (Table 2), were used as dipping seedlings treatment. Healthy cucumber transplants were dipped in each plant extract for $5 \mathrm{~min}$ then raised and left to dry in air before planting. Transplants were planted in pots as mentioned before.

Effect of some fungicides on controlling Sclerotinia rot:

Five fungicides, namely Bellis $38 \%(0.05 \mathrm{~g} / \mathrm{L}$ water), Topsin M70\% (2g /L water), Onest 70\% (1g/L water), Basten $80 \%$ ( $1 \mathrm{~g} / \mathrm{L}$ water) and Hesta70\% (1g /L water) (Table3 ) were used as dipping treatment. Healthy cucumber transplants were dipped in each fungicide solution for $5 \mathrm{~m}$ then raised and left to dry in air before planting. Transplants were planted in pots amended as previously mentioned before.

Integrated management of Sclerotinia rot:
Variants of combinations of the best treatments of this study were applied to cucumber plants artificially inoculated with the pathogen to evaluate the best approach of integrated management for the Sclerotinia rot disease. The mixed treatments were T. hamatum + Bellis , T. album + Bellis + neem, T. hamatum + Topsin + basil, $T$. hamatum + Basten + lemongrass, $T$. album + Onest + onion, T. album + Hesta + nerium, $T$. viride + Basten + garlic, T. viride + Hesta + Plant Guard, T. viride + Onest + Blight Stop, T. viride + Basten + garlic, T. harzianum 2 + Plant Guard + garlic.

\section{Statistical analyses:}

Statistical analyses of all the previously designed experiments have been carried out according to the procedures (ANOVA) reported by Snedecor and Cochran (1989).

\section{RESULTS}

\section{Isolation of the causal organism:}

Cucumber plant samples showing typical Sclerotinia rot symptoms were collected from different localities at different governorates, AlQalyubia (Moshtohor and Toukh), El-Behira (Elbostan), Kafr Elsheikh (Kafr Elsheikh) and South Sinai. Five isolates of Sclerotinia sclerotiorum presented were isolated from five locations of different governorates.

Table 4. Sclerotinia sclerotiorum isolates that isolated from different localities in Egypt.

\begin{tabular}{llll}
\hline Isolate No. & Location & District & Soil type \\
\hline 1 & EL- Behaira & EL-bostan & Sandy \\
2 & Kafr elsheikh & Kafr elsheikh & Clay \\
3 & El Qalyubia & Toukh & Clay \\
4 & El Qalyubia & Moshtohor & Clay \\
5 & Red sea & Sinai & Sandy \\
\hline
\end{tabular}

\section{Pathogenicity results:}

The pathogenicity test of the five isolates of $S$. sclerotiorum were carried out using transplants of cucumber hybrid Torpedo. Data in figure1 indicate that all the tested isolates were pathogenic to cucumber plants. Isolates S1, S2, S3 and S4 were highly virulent, whereas isolate S5 that isolated from the Red Sea was the least virulent. Isolate S3 showed the highest disease incidence and disease severity with $\mathbf{7 7 . 7 7} \%$ and $59.25 \%$, respectively followed by isolate $\mathrm{S} 2$ and isolate S4. On the other hand, isolate S5 showed the least effect in this respect. 


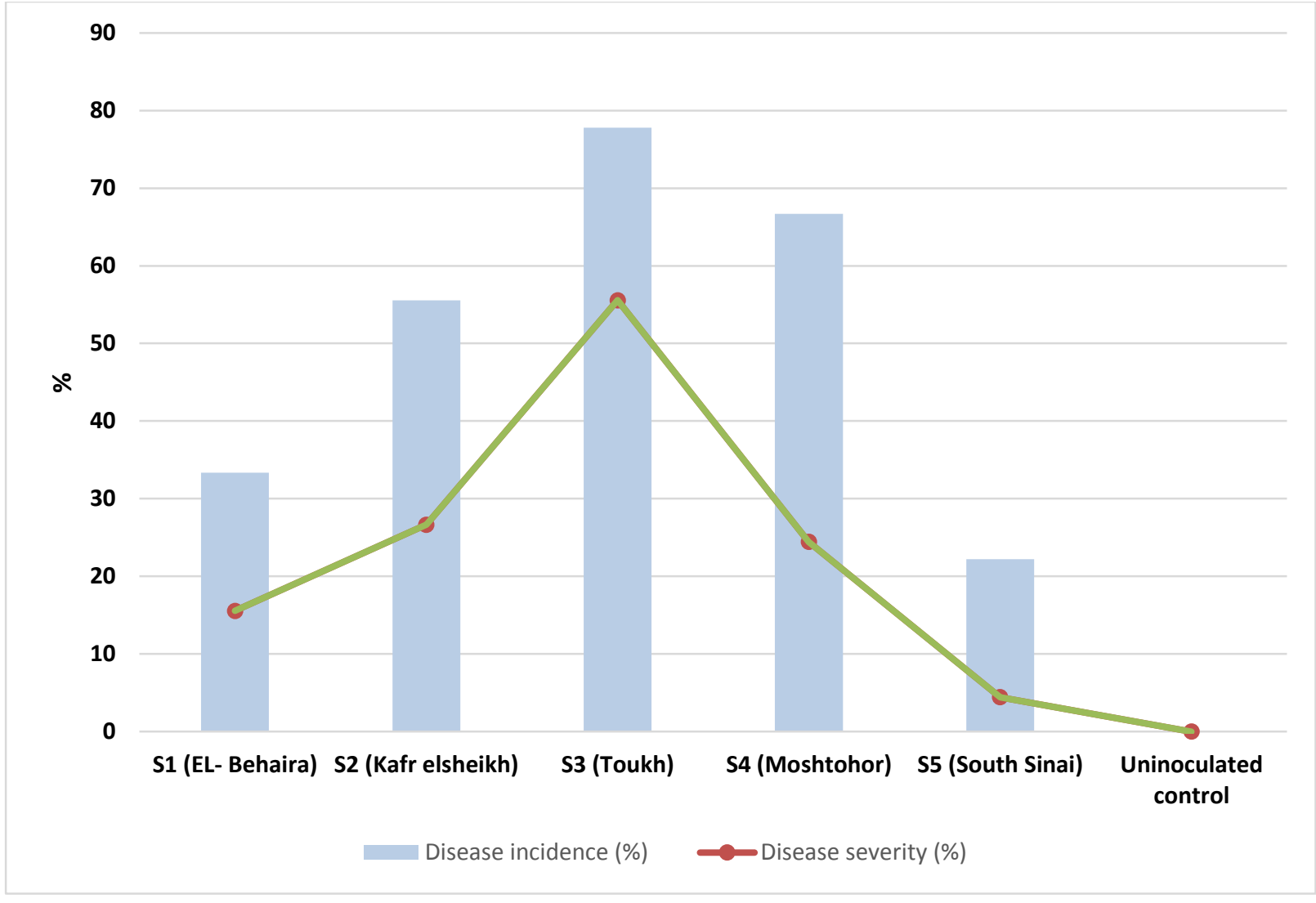

Figure 1: Pathogenicity test of the five S. sclerotiorum isolates that isolated from different localities in Egypt.

Varietal reaction of seven cucumber hybrids to five isolates of $S$. sclerotiorum under greenhouse conditions.

The responses of seven cucumber genotypes to Sclerotinia rot infection incited by $S$. sclerotiorum was studied under greenhouse conditions. Seedlings of cucumber cultivars i.e. Hybrid Vector, C.B140, Smile, Matrix, Torpedo, Beta Alpha and Barracuda seedlings were tested against the five isolates of $S$. sclerotiorum for their response (resistance and susceptibility) to infection by fungus.

Data in Table 5 indicate that all tested cucumber genotypes were susceptible to $S$. sclerotiorum and differed significantly in their susceptibility against $S$. sclerotiorum infection based on disease incidence and disease severity

Results revealed that the reaction of $S$. sclerotiorum (iso No.3) (Toukh isolate) with Torpedo hybrid recorded the highest disease incidence and disease severity ( 80.80 and $89.56 \%$, respectively), followed by isolate 2 with Smile hybrid (79.90 and $80.12 \%$, respectively), the reaction of isolate 1 with Torpedo hybrid comes next with the values 77.93 and $78.90 \%$, respectively . No infection was recorded on Matrix hybrid. All tested cucumber genotypes were varied to the infection percentage with $S$. sclerotiorum.

Table 5. Variety reaction of the seven cucumber hybrids to five isolates of Sclerotinia sclerotiorum under greenhouse conditions.

\begin{tabular}{|c|c|c|c|c|c|c|c|c|c|c|c|c|}
\hline Variety & \multicolumn{2}{|c|}{ Hybrid Vector } & \multicolumn{2}{|l|}{ Smile } & \multicolumn{2}{|c|}{ Matrix } & \multicolumn{2}{|c|}{ Torpedo } & \multicolumn{2}{|c|}{ Beta Alpha } & \multicolumn{2}{|c|}{ Barracuda } \\
\hline $\begin{array}{l}\text { Fungal } \\
\text { isolate } \\
\text { NO. }\end{array}$ & $\begin{array}{l}\text { DI } \\
(\%)\end{array}$ & $\begin{array}{l}\text { DS } \\
(\%)\end{array}$ & $\begin{array}{l}\text { DI } \\
(\%)\end{array}$ & $\begin{array}{l}\text { DS } \\
(\%)\end{array}$ & $\begin{array}{l}\text { DI } \\
(\%)\end{array}$ & $\begin{array}{l}\text { DS } \\
(\%)\end{array}$ & $\begin{array}{l}\text { DI } \\
(\%)\end{array}$ & $\begin{array}{l}\text { DS } \\
(\%)\end{array}$ & $\begin{array}{l}\text { DI } \\
(\%)\end{array}$ & $\begin{array}{l}\text { DS } \\
(\%)\end{array}$ & $\begin{array}{l}\text { DI } \\
(\%)\end{array}$ & $\begin{array}{l}\text { DS } \\
(\%)\end{array}$ \\
\hline 1 & 66.70 & 57.76 & 44.40 & 40.00 & 0.00 & 0.00 & 77.93 & 78.90 & 33.30 & 22.23 & 44.40 & 31.11 \\
\hline 2 & 55.61 & 46.63 & 79.90 & 80.12 & 44.45 & 33.33 & 66.00 & 50.53 & 77.83 & 71.13 & 55.60 & 28.90 \\
\hline 3 & 66.72 & 60.00 & 77.81 & 57.66 & 33.30 & 17.76 & 80.80 & 89.56 & 66.70 & 55.53 & 77.82 & 57.76 \\
\hline 4 & 44.40 & 42.23 & 66.79 & 48.86 & 33.32 & 20.00 & 44.42 & 15.57 & 66.70 & 57.80 & 77.86 & 31.13 \\
\hline 5 & 88.93 & 73.33 & 66.72 & 57.80 & 45.00 & 50.86 & 55.60 & 33.34 & 33.30 & 24.43 & 55.61 & 26.66 \\
\hline L.S.D & 0.526 & 0.526 & 0.526 & 0.968 & 0.664 & 0.664 & 0.525 & 0.525 & 0.525 & 0.525 & 0.525 & 0.525 \\
\hline
\end{tabular}


In vitro effect of biological agents on growth of $S$. sclerotiorum.

Data in Figure2 show that all used antagonistic fungi reduced growth of $S$. sclerotiorum. Trichoderma hamatum was the best antagonistic fungus in inhibiting the mycelial linear growth by $84.82 \%$ followed by $T$. viride by $74.82 \%$ growth reduction, compared to control. T. harzianum, and T. album came next in this respect. Meanwhile, T. harzianum 2 caused $72.96 \%$ growth reduction. In the other respect, Bacillus subtilis was more effective as antagonistic bacteria and reduced growth of S. sclerotiorum by $60.00 \%$ followed by Pseudomonas fluorescens causing $48.86 \%$ growth reduction.

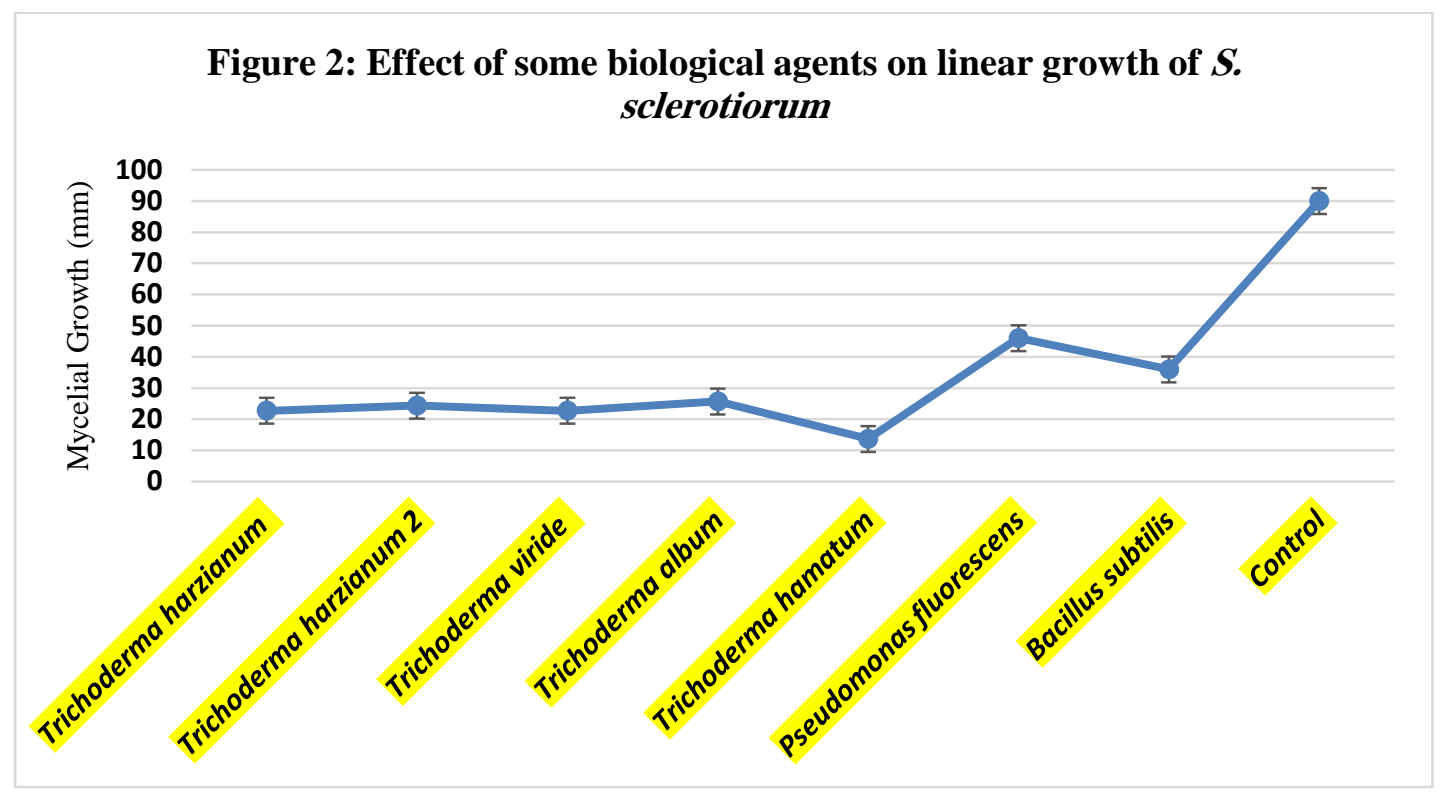

Effect of biocides on linear growth of $S$. sclerotiorum:

Different concentrations of the two tested biocides Plant guard and Blight stop showed their effects on liner growth and sclerotia formation of $S$. Sclerotiorum in vitro.

Data in Table 6 indicate that all tested biocides Plant guard and Blight stop reduced the mycelial linear growth and sclerotial formation at their high concentrations than the low ones. In this respect, the biocides, Blight Stop at $3 \mathrm{~g} / \mathrm{L}$ was the best effective bio fungicides where it reduced the growth of $S$. sclerotiorum to $90 \%$ and $100 \%$, followed by Plant Guard at $3 \mathrm{~g} / \mathrm{L}$. However, Plant Guard at $2 \mathrm{~g} / \mathrm{L}$ was the least effective on sclerotial formation.

Table 6. Effect of biocides with different concentrations on the growth and sclerotial formation of S. sclerotiorum in vitro:

\begin{tabular}{|c|c|c|c|c|c|}
\hline \multirow[b]{2}{*}{ Treatment } & \multirow{2}{*}{$\begin{array}{l}\text { Concentration } \\
\text { (g/L) }\end{array}$} & \multirow{2}{*}{$\begin{array}{l}\text { Mycelial } \\
\text { growth (mm) }\end{array}$} & \multirow{2}{*}{$\begin{array}{l}\text { Sclerotial } \\
\text { formation (No.) }\end{array}$} & \multicolumn{2}{|c|}{ Efficacy (\%) } \\
\hline & & & & $\begin{array}{l}\text { Mycelial } \\
\text { growth }\end{array}$ & $\begin{array}{l}\text { Sclerotial } \\
\text { formation }\end{array}$ \\
\hline \multirow{3}{*}{ Blight Stop } & 1 & 90.00 & 5.00 & 0.00 & 64.28 \\
\hline & 2 & 89.00 & 3.00 & 1.11 & 78.57 \\
\hline & 3 & 0.00 & 0.00 & 100 & 100 \\
\hline \multirow{3}{*}{ Plant Guard } & 1 & 90.00 & 4.00 & 0.00 & 71.42 \\
\hline & 2 & 83.00 & 13.00 & 7.77 & 7.14 \\
\hline & 3 & 78.00 & 6.00 & 13.33 & 57.14 \\
\hline Control & -------- & 90.00 & 14.00 & 0.00 & 0.00 \\
\hline LSD $0.05=$ & & 0.21 & 0.68 & ------ & ------ \\
\hline
\end{tabular}

Effect of plant extracts on the growth and sclerotial formation of $S$. sclerotiorum in vitro:

Results in Table 7 show that, both growth and production of sclerotia of $S$. sclerotiorum were significantly reduced by all tested plant extracts compared with control. Regarding linear growth, neem extract at $20 \%$ inhibited the mycelial growth by $35.55 \%$ and production of sclerotia by $62.21 \%$, followed by garlic extract at $20 \%$ which reduced linear growth and production of sclerotia by 28.17 and $75.55 \%$, respectively. Other treatments were slightly effective on growth of $S$. sclerotiorum, but decreased sclerotial formation, especially lemon grass extract at $20 \%$ followed by onion extract at $10 \%$, compared to the control. 
Table 7. Effect of plant extracts on the growth and sclerotial formation of $S$. sclerotiorum in vitro.

\begin{tabular}{|c|c|c|c|c|c|}
\hline Treatment & $\begin{array}{l}\text { Concentration } \\
(\mathrm{g} / \mathrm{L})\end{array}$ & $\begin{array}{l}\text { Mycelial } \\
\text { growth (mm) }\end{array}$ & $\begin{array}{l}\text { Sclerotial } \\
\text { formation (No.) }\end{array}$ & $\begin{array}{l}\text { Efficacy (\%) } \\
\text { Mycelial } \\
\text { growth }\end{array}$ & $\begin{array}{l}\text { Sclerotial } \\
\text { formation } \\
\end{array}$ \\
\hline \multirow[t]{3}{*}{ Basil } & $5 \%$ & 88.88 & 36.66 & 1.24 & -52.75 \\
\hline & $10 \%$ & 88.83 & 32.33 & 1.3 & -34.70 \\
\hline & $20 \%$ & 86.33 & 14.33 & 4.07 & 40.29 \\
\hline \multirow[t]{3}{*}{ Garlic } & $5 \%$ & 75.83 & 7.33 & 15.75 & 69.46 \\
\hline & $10 \%$ & 69.50 & 5.66 & 22.78 & 62.22 \\
\hline & $20 \%$ & 64.66 & 3.66 & 28.16 & 76.41 \\
\hline \multirow[t]{3}{*}{ Lemon grass } & $5 \%$ & 87.50 & 14.33 & 2.78 & 40.29 \\
\hline & $10 \%$ & 83.00 & 6.66 & 7.77 & 72.25 \\
\hline & $20 \%$ & 81.83 & $\mathbf{0 . 3 3}$ & 9.07 & 98.62 \\
\hline \multirow[t]{3}{*}{ Nerium } & $5 \%$ & 85.83 & 11.66 & 4.63 & 51.41 \\
\hline & $10 \%$ & 83.16 & 29.33 & 7.6 & -22.20 \\
\hline & $20 \%$ & $\mathbf{7 7 . 3 3}$ & 9.33 & 14.07 & 61.125 \\
\hline \multirow[t]{3}{*}{ Neem } & $5 \%$ & 58.83 & 7.00 & 34.63 & 70.83 \\
\hline & $10 \%$ & 58.83 & 9.00 & 34.63 & 62.5 \\
\hline & $20 \%$ & 58.00 & 5.66 & 35.55 & 76.41 \\
\hline \multirow[t]{3}{*}{ Onion } & $5 \%$ & 89.00 & 9.33 & 1.11 & 61.125 \\
\hline & $10 \%$ & 83.33 & 6.33 & 7.41 & 73.625 \\
\hline & $20 \%$ & 74.83 & 15.66 & 16.85 & 34.75 \\
\hline Control & -------- & 90.00 & 24.00 & 0.00 & 0.00 \\
\hline LSD $0.05=$ & & 0.44 & 0.45 & -------- & -------- \\
\hline
\end{tabular}

Effect of fungicides with different concentrations on the growth and sclerotial formation of $S$. sclerotiorum in vitro:

Results in Table 8 show that, the growth and sclerotial formation of $S$. sclerotiorum were completely inhibited by most tested fungicides. All concentration of the fungicide Topsin M70 stopped the growth of the fungus, while the high concentration of the fungicide Bellis showed the same trend. On the other hand, all concentrations of the fungicides onest, basten and hesta gave the least effect in stopping the growth of $S$. sclerotiorum.

Table 8: Effect of fungicides on the growth and Sclerotial formation of S. sclerotiorum in vitro.

\begin{tabular}{|c|c|c|c|c|c|}
\hline \multirow[b]{2}{*}{ Treatment } & \multirow[b]{2}{*}{$\begin{array}{c}\text { Concentration } \\
\mathrm{g} / \mathrm{L})(\end{array}$} & \multirow[b]{2}{*}{$\begin{array}{c}\text { Mycelial } \\
\text { growth (mm) }\end{array}$} & \multirow[b]{2}{*}{$\begin{array}{l}\text { Sclerotial } \\
\text { formation }\end{array}$} & \multicolumn{2}{|c|}{ Efficacy } \\
\hline & & & & $\begin{array}{l}\text { Mycelial } \\
\text { growth (mm) }\end{array}$ & $\begin{array}{l}\text { Sclerotial } \\
\text { formation }\end{array}$ \\
\hline \multirow{4}{*}{ Topsin M } & 1 & 39.16 & 0.00 & 56.43 & 100 \\
\hline & 2 & 34.36 & 0.00 & 61.81 & 100 \\
\hline & 3 & 4.66 & 0.00 & 94.81 & 100 \\
\hline & 1 & 0.00 & 0.00 & 100 & 100 \\
\hline \multirow[t]{2}{*}{ Bellis } & 2 & 0.00 & 0.00 & 100 & 100 \\
\hline & 3 & 0.00 & 0.00 & 100 & 100 \\
\hline \multirow{3}{*}{ Onest $70 \%$} & 0.5 & 90.00 & 0.00 & $\mathbf{0 . 0 0}$ & 100 \\
\hline & 1 & 88.30 & 0.00 & 1.88 & 100 \\
\hline & 1.5 & 33.00 & 0.00 & 63.33 & 100 \\
\hline \multirow{4}{*}{ Basten80\% } & 0.5 & 78.00 & 0.00 & 13.33 & 100 \\
\hline & 1 & 68.00 & 0.00 & 24.44 & 100 \\
\hline & 1.5 & 25.00 & 0.00 & 72.22 & 100 \\
\hline & 0.5 & 0.00 & 0.00 & 100 & 100 \\
\hline \multirow[t]{2}{*}{ Hesta70\% } & 1 & 0.00 & 0.00 & 100 & 100 \\
\hline & 1.5 & 0.00 & 0.00 & 100 & 100 \\
\hline Control & -------- & 90.00 & 24 & $\mathbf{0 . 0 0}$ & 0.00 \\
\hline L.S.D & At $0.05 \%$ & 0.361 & 0.00 & ------ & -------- \\
\hline
\end{tabular}

Greenhouse experiments:

Effect of some antagonistic fungi and bacteria on white rot disease, and some growth and production characters of cucumber plants.
Data in Table 9 indicate that all tested isolates of Trichoderma spp. significantly reduced white rot disease incidence and disease severity, as well as increased some growth parameters of cucumber 
plants. The highest increase in fresh and dry weight of shoot and root, plant height, number of leaves and number of fruits were obtained with T. album. The tested isolates of antagonistic bacteria significantly reduced the white rot disease incidence and severity, as well as it exhibited an increase of some growth characteristics compared to the controls. The highest increases in the growth were recorded in case of treatment with Bacillus subtilis. Disease incidence and disease severity recorded 33.33 and $33.30 \%$, in case of B. subtilis compared to 100 and $86.23 \%$ in control, respectively, followed by Pseudomonas fluorescens, where disease incidence and disease severity recorded 23.30 and $46.70 \%$, respectively.

Table 9. Effect of some antagonistic fungi and bacteria on white rot disease and some growth and production characters of cucumber plants.

\begin{tabular}{|c|c|c|c|c|c|c|c|c|c|}
\hline \multirow[t]{2}{*}{ Treatments } & \multirow[t]{2}{*}{ DI (\%) } & \multirow[t]{2}{*}{ DS (\%) } & \multicolumn{2}{|c|}{ FW (g) } & \multicolumn{2}{|c|}{ DW (g) } & \multirow{2}{*}{$\begin{array}{l}\text { Plant } \\
\text { height } \\
(\mathrm{cm})\end{array}$} & \multirow{2}{*}{$\begin{array}{l}\text { Number } \\
\text { of } \\
\text { leaves/per } \\
\text { plant }\end{array}$} & \multirow{2}{*}{$\begin{array}{l}\text { Number } \\
\text { of fruits/ } \\
\text { per plant }\end{array}$} \\
\hline & & & Root & Shoot & Root & Shoot & & & \\
\hline T. harzianum & 33.30 & 66.70 & 1.70 & 15.49 & 0.17 & 2.07 & 42 & 10 & 4 \\
\hline T. harzianum 2 & 33.00 & 60.00 & 4.55 & 33.09 & 0.60 & 4.07 & 120 & 8 & 10 \\
\hline T. viride & 33.30 & 53.30 & 7.51 & 36.95 & 0.19 & 4.61 & 69 & 15 & 6 \\
\hline T. album & 22.22 & 53.30 & 8.59 & 72.13 & 0.90 & 8.84 & 90 & 13 & 9 \\
\hline T. hamatum & 23.22 & 26.70 & 2.00 & 36.69 & 0.18 & 4.86 & 20 & 3 & 2 \\
\hline Ps. fluorescens & 33.33 & 46.70 & 6.68 & 64.69 & 0.98 & 6.61 & 39 & 8 & 3 \\
\hline B. subtilis & 33.39 & 33.30 & 8.34 & 68.05 & 1.00 & 6.95 & 58 & 10 & 4 \\
\hline Control I & 100.00 & 86.23 & 0.87 & 17.98 & 0.06 & 1.33 & 16 & 2 & $\mathbf{0}$ \\
\hline Control II & 00.00 & 00.00 & 0.94 & 22.45 & 0.08 & 1.56 & 18 & 3 & 1 \\
\hline L.S.D. at $0.05 \%$ & 0.373 & 0.373 & 0.363 & 0.370 & $\mathbf{0 . 1 3 5}$ & 0.370 & 0.370 & 0.373 & \\
\hline
\end{tabular}

Control I: Inoculated soil, Control II: Uninoculated soil

Effect of commercial biocides on white rot disease and some growth and production characters of cucumber:

Data in Table 10 indicate that all tested commercial biocides Blight stop, and plant guard significantly reduced white rot disease incidence and disease severity, as well as it increased the growth characters of cucumber plants. The highest increase in fresh and dry weights of shoot and root, plant height, number of leaves and number of fruits were achieved by Blight Stop at concentration of $3 \mathrm{~mL} / \mathrm{L}$.

Table 10. Effect of commercial biocides on white rot disease and some growth and production characters of cucumber.

\begin{tabular}{|c|c|c|c|c|c|c|c|c|c|c|}
\hline \multirow[t]{2}{*}{ Biocide } & \multirow{2}{*}{$\begin{array}{l}\text { Conc. } \\
(\mathrm{mL} / \mathrm{L})\end{array}$} & \multirow[t]{2}{*}{ DI (\%) } & \multirow[t]{2}{*}{ DS (\%) } & \multicolumn{2}{|c|}{ FW (g) } & \multicolumn{2}{|c|}{ DW (g) } & \multirow{2}{*}{$\begin{array}{l}\text { Plant } \\
\text { height } \\
\text { (cm) }\end{array}$} & \multirow{2}{*}{$\begin{array}{l}\text { Number } \\
\text { of leaves }\end{array}$} & \multirow{2}{*}{$\begin{array}{l}\text { Number } \\
\text { of fruits }\end{array}$} \\
\hline & & & & Root & Shoot & Root & Shoot & & & \\
\hline Blight & 1 & 33.33 & 33.33 & 5.94 & 21.05 & 0.24 & 2.15 & 20 & 14 & 2 \\
\hline \multirow[t]{2}{*}{ Stop } & 2 & 33.00 & 33.33 & 5.00 & 24.06 & 0.63 & 3.13 & 46 & 12 & 3 \\
\hline & 3 & 11.11 & 13.33 & 8.70 & 49.00 & 1.66 & 6.00 & 49 & 15 & 5 \\
\hline Plant & 1 & 33.66 & 33.33 & 6.65 & 16.28 & 0.28 & 0.90 & 30 & 9 & 3 \\
\hline \multirow[t]{2}{*}{ Guard } & 2 & 33.33 & 33.33 & 7.26 & 17.86 & 1.11 & 1.90 & 40 & 10 & 3 \\
\hline & 3 & 33.00 & 33.33 & 8.14 & 48.16 & 1.50 & 5.59 & 29 & 12 & 4 \\
\hline Control I & & 00.00 & 0.00 & 0.94 & 22.45 & 0.08 & 1.56 & 18 & 3 & 1 \\
\hline Control II & & 100.00 & 100.00 & $\mathbf{0 . 8 7}$ & 17.98 & 0.06 & 1.33 & 16 & 2 & 0 \\
\hline L.S.D at 0. & & 0.379 & 0.379 & 0.447 & 0.00 & 0.499 & 0.340 & 0.00 & 0.00 & 0.379 \\
\hline
\end{tabular}

Control I: Uninoculated soil, Control II: Inoculated soil

Effect of plant extracts on white rot disease and some growth and production characters of cucumber.

Six plant extracts, i.e; basil, lemon grass, nerium, neem, garlic and onion were tested for their effects on white rot disease incidence and severity under greenhouse condition. Data in Table 11 indicate that all tested plant extracts reduced the growth of $S$. sclerotiorum. In this respect, the best reduction percentage in both disease incidence and disease severity of white rot was obtained with the concentration of $20 \%$ of all tested plant extracts. Neem and onion extracts were the best effective plant extract by completely reduced the disease incidence and severity as well as, it caused an increase in fresh and dry weights of shoot and root, plant height, number of leaves and number of fruits compared to control. 
Table 11. Effect of plant extracts at concentration $20 \%$ on white rot disease and some growth and production characters of cucumber

\begin{tabular}{|c|c|c|c|c|c|c|c|c|c|}
\hline \multirow[t]{2}{*}{ Treatment } & \multirow[t]{2}{*}{ DI (\%) } & \multirow[t]{2}{*}{ DS (\%) } & \multicolumn{2}{|l|}{ FW(g) } & \multicolumn{2}{|c|}{ DW $(g)$} & \multirow{2}{*}{$\begin{array}{l}\text { Plant } \\
\text { height } \\
(\mathrm{cm}\end{array}$} & \multirow{2}{*}{$\begin{array}{l}\text { Number } \\
\text { of leaves }\end{array}$} & \multirow{2}{*}{$\begin{array}{l}\text { Number } \\
\text { of fruits }\end{array}$} \\
\hline & & & Root & Shoot & Root & Shoot & & & \\
\hline Basil & 33.33 & 46.71 & 12.96 & 19.34 & 2.45 & 2.45 & 60 & 14 & 4 \\
\hline Garlic & 22.22 & 20.00 & 3.14 & 35.61 & 0.77 & 4.37 & 83 & 18 & 5 \\
\hline Lemon grass & 11.11 & 6.73 & 6.18 & 40.96 & 1.05 & 8.34 & 61 & 19 & 5 \\
\hline Nerium & 33.33 & 33.33 & 5.23 & 40.40 & 0.29 & 7.39 & 55 & 11 & 3 \\
\hline Neem & 0.00 & 0.00 & 8.44 & 52.39 & 2.78 & 8.50 & 89 & 19 & 7 \\
\hline Onion & 0.00 & 0.00 & 6.38 & 49.88 & 1.44 & 7.84 & 85 & 18 & 6 \\
\hline Control I & 100.00 & 100.00 & 0.87 & 17.98 & 0.06 & 1.33 & 16 & 2 & $\mathbf{0}$ \\
\hline Control II & 00.00 & 00.00 & 0.94 & 22.45 & 0.08 & 1.56 & 18 & 3 & 1 \\
\hline L.S.D. 0.05 & 0.555 & 0.555 & 0.340 & 0.00 & 0.466 & 0.496 & 0.982 & 0.00 & 0.516 \\
\hline
\end{tabular}

Control I: Inoculated soil. Control II : Uninoculated soil .

Effect of fungicides as root dipping treatment on white rot disease and some characters of growth of cucumber plants:

Results in Table 12 indicate that, five fungicides of Topsin M, Bellis, Bastine, Onest and Hesta were evaluated for controlling cucumber white rot disease under greenhouse conditions. bellis was the most effective fungicide treatment for reducing the disease incidence of cucumber plants and it caused an increase of fresh and dry weight of shoot and root, plant height, number of leaves and number of fruits compared with untreated control.

Table 12. Effect of some fungicides as root dipping treatment on white rot disease incidence and some growth characters of cucumber plants

\begin{tabular}{|c|c|c|c|c|c|c|c|c|c|}
\hline \multirow[t]{2}{*}{ Treatment } & \multirow[t]{2}{*}{ DI\% } & \multirow[t]{2}{*}{ DS\% } & \multicolumn{2}{|l|}{ FW $(g)$} & \multicolumn{2}{|l|}{ DW $(g)$} & \multirow{2}{*}{$\begin{array}{l}\text { Plant } \\
\text { height }\end{array}$} & \multirow{2}{*}{$\begin{array}{l}\text { Number } \\
\text { of leaves }\end{array}$} & \multirow{2}{*}{$\begin{array}{l}\text { Number } \\
\text { of fruits }\end{array}$} \\
\hline & & & Root & Shoot & Root & Shoot & & & \\
\hline Topcin M & 33.77 & 80.0 & 10.51 & 31.60 & 0.77 & 3.73 & 77 & 10 & 6 \\
\hline Bellis & 33.30 & 40.0 & 15.55 & 90.33 & 4.38 & 9.37 & 80 & 18 & 7 \\
\hline Bastne 80 & 33.33 & 46.7 & 11.64 & 42.50 & 2.58 & 6.60 & 65 & 13 & 6 \\
\hline Onest 70 & 33.30 & 41.31 & 12.26 & 89.10 & 3.76 & 8.51 & 79 & 15 & 6 \\
\hline Hesta & 33.33 & 66.7 & 14.78 & 69.05 & 3.25 & 6.66 & 35 & 12 & 2 \\
\hline Control I & 00.00 & 00.00 & 0.94 & 22.45 & 0.08 & 1.56 & 18 & 3 & 1 \\
\hline Control II & 100.00 & 92.32 & 0.87 & 17.98 & 0.06 & 1.33 & 16 & 2 & $\mathbf{0}$ \\
\hline L.S.D. 0.05 & 0.516 & 0.496 & 0.499 & 0.518 & 0.379 & 0.531 & 0.379 & 0.379 & 0.379 \\
\hline
\end{tabular}

DI: disease incidence, DS: disease severity, FW: Fresh weight, DW: Dry weight

Control I: Un-inoculated soil. Control II: inoculated soil.

Effect of integrated management on white rot disease and some growth characters of cucumber plants:

This experiment was carried out to evaluate the combinations of different management approaches for their efficiency to control white rot disease of cucumber under greenhouse conditions. Data in Table (13) indicate that, all tested combinations reduced white rot disease incidence and disease severity, as well as it caused an increase of fresh and dry weights of shoot and root, plant height, number of leaves and number of fruits. In this respect, the application of $\boldsymbol{T}$. album + Hesta + nerium, T. album + Onest + onion, T. viride + Basten + garlic, $T$. viride + Hesta + Plant Guard and $T$. virde + Onest + Blight Stop, $T$. hamatum + Bellis, were highly reduced white rot disease incidence and disease severity. On the other hand, the other treatments recorded moderate effect.

Table 13. Effect of integrated management on white rot disease and some growth characters of cucumber plants. 


\begin{tabular}{|c|c|c|c|c|c|c|c|c|c|}
\hline \multirow[t]{2}{*}{ Treatments } & \multirow[t]{2}{*}{ DI (\%) } & \multirow[t]{2}{*}{ DS (\%) } & \multicolumn{2}{|c|}{ FW (g) } & \multicolumn{2}{|c|}{ DW (g) } & \multirow{2}{*}{$\begin{array}{l}\text { Plant } \\
\text { height } \\
\text { (cm) }\end{array}$} & \multirow{2}{*}{$\begin{array}{l}\text { Number } \\
\text { of leaves }\end{array}$} & \multirow{2}{*}{$\begin{array}{l}\text { Number } \\
\text { of fruits }\end{array}$} \\
\hline & & & Root & Shoot & Root & Shoot & & & \\
\hline T. hamatum + Bellis & 22.22 & 40.00 & 2.28 & 20.12 & 0.18 & 2.09 & 90 & 20 & 8 \\
\hline T. album + Bellis + neem & 11.11 & 6.76 & 2.97 & 27.86 & 0.20 & 3.02 & 110 & 24 & 10 \\
\hline T. hamatum + Topsin + basil & 22.22 & 13.33 & 3.42 & 32.43 & 0.33 & 4.58 & 60 & 16 & 6 \\
\hline $\begin{array}{l}\text { T. hamatum }+ \text { Basten }+ \\
\text { lemongrass }\end{array}$ & 11.11 & 6.66 & 3.80 & 61.48 & 0.34 & 1.57 & 49 & 9 & 4 \\
\hline T. album + Hesta + nerium & 33.33 & 20.04 & 5.44 & 66.35 & 0.88 & 7.35 & 53 & 10 & 5 \\
\hline T. album + Onest + onion & 33.33 & 40.21 & 3.76 & 56.43 & 0.56 & 4.81 & 73 & 15 & 5 \\
\hline T. viride + Basten + garlic & 33.33 & 46.75 & 1.40 & 27.59 & 0.22 & 2.76 & 45 & 11 & 3 \\
\hline $\begin{array}{l}\text { T. viride }+ \text { Hesta }+ \text { Plant } \\
\text { Guard }\end{array}$ & 33.33 & 60.00 & 2.00 & 49.98 & 0.82 & 3.98 & 78 & 10 & 4 \\
\hline T. virde + Onest + Blight Stop & 33.33 & 53.33 & 1.97 & 28.86 & 0.45 & 2.56 & 30 & 7 & 1 \\
\hline T. viride + Basten + garlic & 33.33 & 46.75 & 1.40 & 27.59 & 0.22 & 2.76 & 45 & 11 & 3 \\
\hline $\begin{array}{l}\text { T. harzianum } 2+\text { Plant } \\
\text { Guard+ garlic }\end{array}$ & 22.22 & 53.33 & 1.34 & 48.92 & 0.72 & 4.37 & 80 & 16 & 6 \\
\hline Control I & 100.00 & 100.00 & 0.87 & 17.8 & 0.06 & 1.33 & 16 & 2 & $\mathbf{0}$ \\
\hline Control II & 00.00 & 00.00 & 0.94 & 22.45 & 0.08 & 1.56 & 18 & 3 & 1 \\
\hline L.S.D at $0.5 \%$ & 0.785 & 0.289 & 0.541 & 0.289 & 0.871 & 0.289 & 0.214 & 0.214 & 0.00 \\
\hline
\end{tabular}

Control I: Inoculated soil, Control II : Uninoculated soil

\section{Discussion}

Fungal soil-borne diseases are among the most serious problems threatening cucumber cultivation in Egypt, especially white rot disease incited with Sclerotinia sclerotiorum (Lib.) de Bary. The devastating effect is due to their difficult control attributed mainly to the long survival of pathogens' resting structures, their wide host range and lack of genetic resistance. Furthermore, excessive application of chemical fertilizers and pesticides has led to health and environmental problems. (Hariprasad and Niranjana, 2009).

Five isolates of Sclerotinia sclerotiorum were isolated from five locations of four different governorates (EL-Behaira, South Sinai, Qaluobiya (Toukh and Moshtohor) and Kafr Elshaikh). The obtained 5 isolates of $S$. sclerotiorum significantly differed in their virulence. Isolate No. 3 showed the highest disease incidence and disease severity with $\mathbf{7 7 . 7 7} \%$ and $59.25 \%$, respectively followed by isolate No. 2 and 4. In the other hand, isolate No. 1 was the least virulent isolate. These results agree with (Hassan, 2017).

Seedlings of cucumber cultivars i.e. Hybrid Vector, C.B140, Smile, Matrix, Torpedo, Beta Alpha and Barracuda seedlings were tested against the five isolates of $S$. sclerotiorum for studying their response (resistance and susceptibility) to infection by fungus. All tested cucumber genotypes were susceptible to $S$. sclerotiorum and different significantly in their susceptibility against $S$. sclerotiorum infection (AbdEl-Kader, 2013).

All tested cucumber cultivars were susceptible to infection with white rot disease. The highest infection was recorded with cvs. Beta Alpha and Torpedo, they recorded disease infection as 88.90 and $77.80 \%$ after 30 days of sowing, respectively. Followed by Hybrid Vector, C.B140, Smile, Matrix and Barracuda.
According to the effect of antagonists, Trichoderma hamatum and Bacillus subtilis were the best antagonistics in inhibiting the mycelial growth of S. sclerotiorum followed by Trichoderma viride. and Pseudomonas fluorescens. These results agree with the results of Budge et al. 1995, Xu, et al (2004), Singh 2010 and Abdeljalil et al., 2016 who reported that, T. harzianum T3 and commercial preparation T102 were applied at $100 \mathrm{~mL}$ as suspensions of $10^{5}$ spores $/ \mathrm{mL}$ through watering to each cucumber plant, the plants were treated 3 times during the vegetative period by foliar spraying at the same concentration as at planting (50 L/ 120 plants). Application of $T$. harzianum antagonists increased yield. All treatments inhibited development of Sclerotinia spp. In vivo tests, both antagonists were effective in controlling the disease in rape and Indian mustard in India but $T$. viride was more effective (Amer $\boldsymbol{e t}$ al., 2010 and Baharlouei et al., 2011).

Indeed, a successful biocontrol agent is generally equipped with several attributes which often promotes plant growth as efficiently as it inhibits fungal growth by efficient root colonization, phytohormone production and nutrient competition (Saraf et al., 2014). Also, Abdullah et al., (2008) showed that $T$. harzianum and Bacillus amyloliquefaciens inhibited the growth and production of mycelia and sclerotia. $T$. harzianum and $B$. amyloliquefaciens appeared to exhibit mycoparasitism and antibiosis respectively, in vitro. Matroudi et al., (2009) reported that, Trichoderma harzianum-8, T. atroviride PTCC5220 and T. longibrachiatum PTCC5140 showed high growth inhibition of two phytopathogenic isolates of S. sclerotiorum (S1 and S2) in vitro (Zhang et al., 2008).

Both growth and production of sclerotia of $S$. sclerotiorum were significantly reduced by all tested plant extracts compared with control. Regarding linear 
growth, neem at 20 and $35.55 \%$ inhibited the mycelial growth and production of sclerotia followed by garlic at $20 \%$ which reduced linear growth and production of sclerotia by 28.17 and $75.55 \%$ respectively. Ojaghian et al., (2014). The objective of any study was to assess the antifungal potential of plant crude extracts derived from cinnamon and rosemary against three isolates of Sclerotinia sclerotiorum under in vitro and in vivo conditions.

All the tested commercial biocides significantly reduced white rot disease incidence and disease severity, the highest increase in fresh and dry weight of shoot and root, Plant height, Number of leaves and Number of fruits were in case of treatment with Blight stop at concentrations $3 \mathrm{~cm} 3 /$ liter. Soil organic amendments serve as a source of nutrients that result in an increase in the soil microbial population, which may influence disease suppression. This suggests that toxic substances from organic matter and mycoparasitism by the biocontrol agents may have contributed to the enhancement of control of $S$. sclerotiorum. These results came in agreement with the results obtained by Mclaren and Fraser, (1996), Jones and Stewart (1997) and Fernando et al. (2006) and Abdullah et al. (2008).

Hassan (2017) indicated that all the tested antagonistic bacteria significantly reduced white rot disease incidence and severity, as well as increased fresh weight and dry weight of shoots and roots. Integrated treatments with compost were effective more than the individual treatment. The highest increase in shoot, root fresh and dry weight was recorded in case of treatment with Ps. fluorescens combined with compost. isolates of Trichoderma spp. significantly reduced white rot disease incidence and disease severity, as well as increased fresh and dry weight of shoots and roots. Integrated treatments with compost were effective more than the individual treatment. The highest increase in shoot, root fresh weight and shoot, root dry weight were effective in case of treatment with $T$. album combined with compost.

Neem was the best effective plant extract where it caused complete reduction of disease incidence and increased fresh and dry weight of shoot and root, plant height, number of leaves and number of fruits compared with control, followed by onion and lemon grass.

All concentration of the fungicide Bellis stopped the growth of S.sclerotiorum. These results are in harmony with the results of Shivpuri et al. (2001) who found that fungicides, carbendazim, thiophenate methyl and phenylpyrrole had inhibited completely the growth of S. sclerotiorum at all concentrations tested in vitro. Muelle et al., (2002) assayed S. sclerotiorum for sensitivity to benomyl, tebuconazole, thiophanate methyl, and vinclozolin in pure cultures on agar medium inoculated soybean seedlings, detached leaves, and experimental field plots. They mentioned that in vitro, vinclozolin was the most effective in inhabiting S. sclerotiorum mycelial growth at 1.0 $\mu \mathrm{g} / \mathrm{mL}$ of PDA. They reported that in greenhouse, benomyl, tebuconazole, thiophanate methyl, and vinclozolin prevented $S$. sclerotiorum from expressing symptoms or sings on leaf tissue.

All the tested integrated management significantly reduced white rot disease incidence and disease severity, as well as increased fresh and dry weight of shoot and root, Plant height, number of leaves and number of fruits. In this respect, $T$. viride + bellis + FeSo4 K2PHO4 and T. hamatum +basten+ Lemon grass and T. album+ bellis+ Neem and Plant guard $+\mathrm{SA}+\mathrm{Neem}+\mathrm{K} 2 \mathrm{HPO} 4+$ blight stop + neem treatment highly significantly reduced white rot disease incidence and disease severity. followed by $T$. hamatum + plant guard+ SA and T. harzianum $2+$ plant guard + Garlic treatment gave the next results (Hassan , 2017).

\section{References:}

Abdeljalil, N.Q.B.; Vallance, J.; Gerbore, J.; Rey, P. and Remadi, M.D. (2016). Bio-suppression of Sclerotinia Stem Rot of Tomato and Biostimulation of Plant Growth Using Tomatoassociated Rhizobacteria. J. Plant Pathol. Microbiol., 7(2): 331-338

Abdel-Kader, M.M.; Abdel-Kareem, F.; ElMougy, N.S. and El-Mohamady, R.S. (2013). Integration between compost, Trichoderma harzianum and essential oils for controlling peanut crown rot under field conditions. Journal of Mycology, 5(4): 1-7.

Abdel-Kader, M.M.; El-Mougy, N.S.; Embaby, E.I. and Lashin, S.M. (2012). Occurrence of Sclerotinia Foliage Blight Disease of Cucumber and Pepper Plants under Protected Cultivation System in Egypt I. Chemical and Biological Control Measures in vitro. Advances in Life Sciences, 2(1): 20-27.

Abd-El-Kareem, F. (2009). Effect of acetic acid fumigation on soil-borne fungi and cucumber root rot disease under greenhouse conditions. Archives of Phytopathology and Plant Protection, 42(3), 213-220.

Abd-El-Moity, T.H. (1985). Effect of single and mixture of Trichoderma harzianum isolates on controlling three different soils -borne pathogens. Egypt. J. Microbiol., 111-120.

Abdullah, M.T.; Nida,Y.; Ali, N.Y. and Suleman, P. (2008). Biological control of Sclerotinia sclerotiorum(Lib.) de Bary with Trichoderma harzianum and Bacillus amyloliquefaciens. Crop Protection, 27:1354- 1359.

Amer, M.A.; Abou Elseoud, I.I.A.; Rasmy, M.R. and Khater, M.M. (2010). Effects of a mycorrhiza fungi, bacteria, and yeast as biological control of Sclerotinia sclerotiorum on the growth of common bean (Phaseolus vulgaris L.). Alexandria science exchange journal, 31 (4) 339352. 
Arul, J. ; Wilson, C. L., El Ghaouth, A., Chalutz, E., Droby, S., Stevens, C. and Lu, J. Y., (1994). Potential of induced resistance to control postharvest diseases of fruits and vegetables. Plant disease, 78(9), 837-844.

Baharlouei, A.; Sharifi-Sirchi, G.R. and Bonjar, G.H.S. (2011). Biological control of Sclerotinia sclerotiorum (oilseed rape isolate) by an effective antagonist Streptomyces. African Journal of Biotechnology, 10(30): 5785-5794.

Bardin, S. D., \& Huang, H. C. (2001). Research on biology and control of Sclerotinia diseases in Canada1. Canadian Journal of Plant Pathology, 23(1), 88-98.

Bolton, M.D.T.; Bart, P.H. J.; and Nelson, B.D. (2006). Sclerotinia sclerotiorum (Lib.) de Bary: biology and molecular traits of cosmopolitan pathogen. Molecular Plant Pathology, 2(7) 1-16.

Budge, S.P.; Mc Quilken, M.P.; Fenlon, J. S.; and Whipps, J. M. (1995). Use of Coniothyrium minitans and Gliocladium virens for biological control of Sclerotinia sclerotiorum in glasshouse lettuce. Biol. Control., 5:513-522.

Callan, N.W.; Mather, D.E. and Miller, J.B. (1990). Biopriming seed treatment for biological control of Pythium ultimum pre-emergence damping-off in sh2 sweet corn. Plant Dis., 74: 368-372.

Fernando, W.G.D.; Nakkeeran, S.; Zhang, Y. and Savchuk, S. (2006). Biological control of Sclerotinia sclerotiorum (Lib.) de Bary by Pseudomonas and Bacillus species on canola petals. Crop Protection,5(26):100-107.

Fravel, D.R. (2005). Commercialization and implementation of biocontrol. Ann. Rev. Phytopathol., 6(43): 337-359.

Grau, C.R.; Radke, V.L. and Gillespie, F.L. (1982). Resistance of soybean cultivars to Sclerotinia sclerotiorum. Plant Dis., 66:506-508.

Hariprasad, P. and Niranjana, S.R. (2009). Isolation and characterization of phosphate solubilizing rhizobacteria to improve plant health of tomato. Plant Soil, 316 (1-2): 13-24.

Harman, G. (2006). Overview of mechanisms and uses of Trichoderma spp. Phytopathology, 96: 190-194.

Hassan , N.G; Mahdy, A.M.M.; Fawzy, R.N; Ahmed, G.A (2017). Integrated management of white mold of tomato caused by Sclerotinia sclerotiorum. M.S.C. Thesis. Faculty of agri. Benha, Univ.156.

Hovius, M.H.Y. and Goldman, I.L. (2004). Evaluation of long-day onions for resistance to white rot infection using greenhouse and laboratory techniques. J. Amer. Soc. Hort. Sci., 129(2):258-265.

Ramesh Singh;(2015). EFFECT OF PLANT EXTRACT ON THE GROWTH OF Sclerotinia sclerotiorum ; Hort. Flora Research Spectrum, 4(4): 386-387
Jones, E.E. and Stewart, A. (1997). Biological control of Sclerotinia minor in lettuce using Trichoderma species. Plant Protection Conf., 154158.

Matroudi, S.; Zamani, M.R. and Motallebi, M. (2009). Antagonistic effects of three species of Trichoderma spp. on Sclerotinia sclerotiorum, the causal agent of canola stem rot. Egyptian Journal of Biology, 11: 37-44.

Maurhofer, M.; Keel, C.; Haas, D. and De'fago, G. (1995). Influence of plant species on disease suppression by Pseudomonas fluorescens strain CHA0 with enhanced antibiotic production. Plant Pathol., 44:40-50.

McLaren, G. F., \& Fraser, J. A. (1996). Pollination compatibility of 'Sundrop'apricot and its progeny in the 'Clutha'series. New Zealand journal of crop and horticultural science, 24(1), 47-53.

Muelle, D.S.; Dorrance, A.E.; Derksen, R.C.; Ozkan, E.; Kurle, J. E.; Grau, C.R.; Gaska, J.M.; Hartman, G.L.; Bradley, C.A.; and Pedersen, W.L. (2002). Efficacy of fungicides on Sclerotinia sclerotiorum and their potential for control of Sclerotinia stem rot on soybean. Plant Pathology, 68:26-1.

Ojaghian, M.R. ; Y. Chen, S. Chen, Z.-q. Cui, G.L. Xie and Zhang, J. (2014). Antifungal and enzymatic evaluation of plant crude extracts derived from cinnamon and rosemary against Sclerotinia carrot rot, Annals of Applied Biology ISSN 0003-4746.

Park, J.L.; Rand, R.E.; Joy, A.E. and King, E.B. (1991). Biological control of Pythium damping off and Aphanomyces root-rot of peas by application of Pseudomonas cepacia or P. fluorescent to seed. Plant Dis., 75: 987-992.

Saraf, M.; Pandya, U. and Thakkar, A. (2014). Role of allelochemicals in plant growth promoting rhizobacteria for biocontrol of phytopathogens. Microbiol. Res., 169: 18-29.

Shivapuri, A.; Bhargava, A.K. and Chippa, H.P. (2001). Sclerotinia sclerotiorum- a new threat to mustard cultivation in Rajasthan, in: Proceeding of Sclerotinia. The XI International Sclerotinia Workshop (C.S. Young and K.J.D. Hughes. Eds.). York 8-12, July, Central Science Laboratory, York, England. pp: 177-178.

Singh NK (2010) Cyamopsis tetragonoloba L Taub inoculated with Arbuscular mycorrhiza and Pseudomonas fluorescens and treated with mustard oil cake overcome Macrophomina rootrot losses. Biol Fertil Soils 46:237-245.

Singh, R.S. (1982). Plant Pathogens "the fungi" Oxford and IBH Publishing Co. New Delhi, Bombay Calcuta, pp: 443.

Snedecor, G.W. and Cochran, W.G. (1989). Statistical methods. Oxford and J. PH. Publishing Com. $8^{\text {th }}$ edition. soil and growth media. In: Integrated Pest and Disease Management of Greenhouse Crops. R. Albajes, M. Lodovica 
Gillino, J. C. van Lenteren \& Y. Elad (Eds.), Kluwer Academic Publishers, Dordrecht, The Netherlands, pp. 139-149.

Wang, H., Bartlett, B. R., Kemberling, H., Eyring, A. D., and Biedrzycki, B. (2015). PD-1 blockade in tumors with mismatch-repair deficiency. New England Journal of Medicine, 372(26), 25092520.

Xu, C; Mo, M and Zhang, K. (2004) Soil fungistasis to Trichoderma spp. and its annulment. J Nanjing Norm Univ 27:77-80.
Zhang, C.X.; Zhao, X.; Jing, Y.X.; Childa, T.; Chen, H. and Shen, S.H. (2008). Phenotypic and biological properties of two antagonist Bacillus subtilis strains. World J Microbiol Biotechnol., 24: 2179-2181.

Zhou, T., \& Boland, G. J. (1998). Biological control strategies for Sclerotinia diseases. Plant-microbe interactions and biological control, 127-156.

\section{تقييم بعض المعاملات الحيوية والمستخلصات النباتية في مكافحة مرض العفن الأبيض علي الخيار المتسبب عن الفطر سكليروتتيا سكليروشيورم \\ ياسمين محمد البطاوي *- نوال عبد المنعم عيسي **- فتحي جاد محمد***- محمد حامد الهباق \\ قسم أمراض النبات - كلية الزراعة بمشتهر - جامعة بنها - مئه}

Corresponding Author: yasmin.elbatawy@fagr.bu.edu.eg

بعتبر مرض العفن الأبيض( الاسكليروتيني) المتنبب عن فطر الاسكليروتينيا Sclerotinia sclerotiorum واحدا من أمراض المجموع الخضري

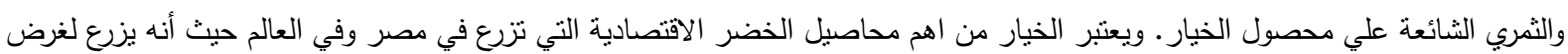
الاستهلاك المحلى والتصدير • وقد أجريت هذه الدراسة بهدف مكافحة مرض العفن الأسكليروتينى علي الخيار عن باستخدام عوامل المكافحة الحيوية والمستخلصات النباتية والمكافحة المتكاملة وذلك بالتكامل بين عوامل المكافحة البيولوجية مع المستخلصات النباتية والمبيدات الحيوية والفطرية تحت ظروف المعمل والصوبة. وفي هذا الإطار أختبر تأثيرخمس عزلات من الترايكودرما وعزلتين من البكتريا وستة مستخلصات نباتية مقارنة بخمسة

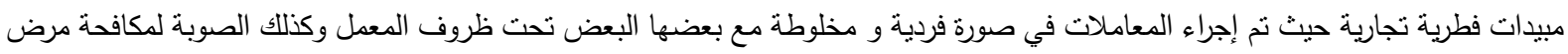

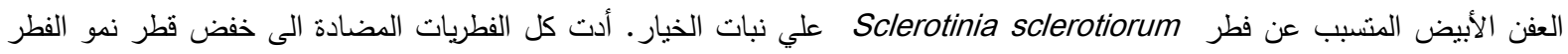
سكليروتينيا سكليروشيورم وكان الفطر ترايكوديرما هاماتم أفضل الفطريات المضادة المختبرة في خفض النمو المبن الميسليومى يتبعه فطري ترايكوديرما

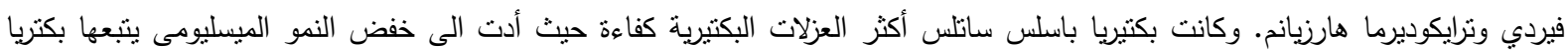
سيدوموناس فلوروسنسس وذلك تحت ظروف المعمل. كما وجد أن استخدام المبيد الحيوي البلايت ستوب اعطى اكثر النتائج معنويه في تقليل النمو الميسليومي للفطر وذلك باستخدام التركيزات المختلفه من المبيد الحيوي وكان افضل التركيزات تتبيطا هو تركيز 3 سم3 / لتر ماءوذللك تحت ظروف المعمل ـ كما أثنارت النتائج المتحصل عليها الى أن كل المستخلصات النباتية المختبرة أدت إلى خفض كلا من النمو الميسليومى للفطر وكذلك تكوين الأجسام الحجرية بزيادة تركيز المستخلص النباتي وكانت أفضل المستخلصات تأثيرا علي النمو الميسليومي للفطر هو مستخلص النيم وذلك الكي تحت ظروف المعمل.كما أدت معظم المبيدات الفطرية المختبرة الى حدوث تثبيط كلي للنمو الميسليومى لفطر سكليروتينيا سكليروشيوم بالاضافة الى منع تكوين الأجسام الحجرية.أما تحت ظروف الصوبة فكانت أفضل المعاملات من الكائنات المضادة هي تريكودرما البيوم وهارزيانم 2 يليهم بكتيريا باسلس ساتلس وبازيدومونس حيث كان لهم نأثيرا كبيرا فى تقليل نسبة وشدة الاصابة بالعفن الابيض وزادت من الوزن الجاف والطازج للمجموع

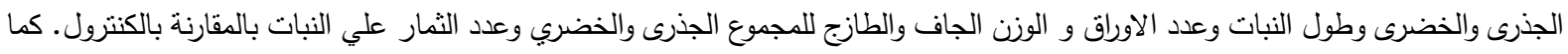

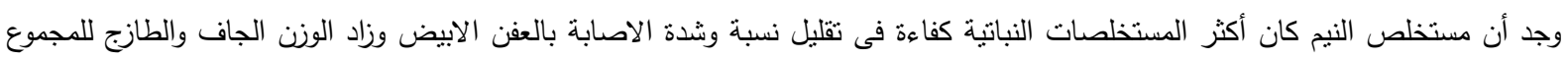
الجذري والخضري بليه في ذلك مستخلص البصل وحثيشة الليمون والثوم علي التوالي. كما اشارت النتائج أن النباتات المعاملة بهميع المبيدات الحيوية التجارية ذات تأثير كبير فى تقليل نسبة وشدة الاصابة بالعفن الابيض وزادت من الوزن الجاف والطازج للمجموع الجذرى والخضرى وطول

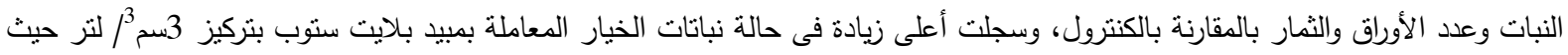

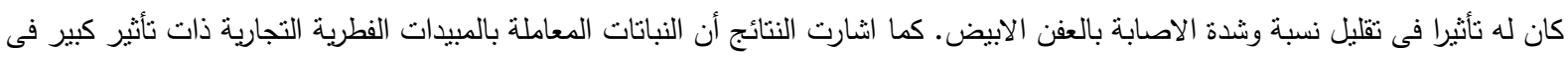

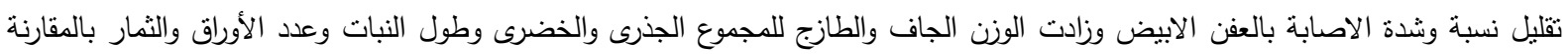

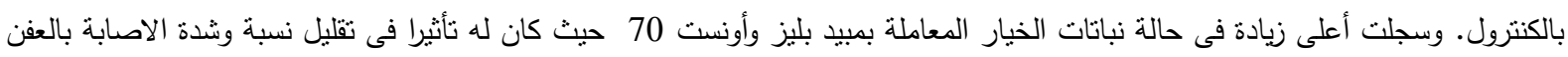

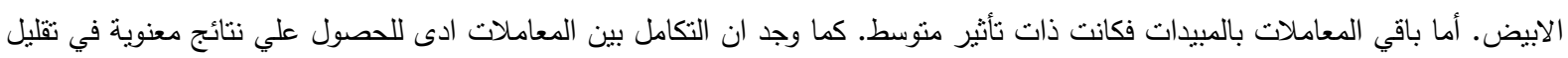
نسبة وشدة الاصابة بالعفن الابيض ، بالإضافه الى انها تعمل على تحسين صفات النمو المختلفة في النبات. 